Peer-Reviewed Article

ISSN: 2162-3104 Print/ ISSN: 2166-3750 Online Volume 6, Issue 4 (2016), pp. 967-983 (C) Journal of International Students http://jistudents.org/

\title{
Critical Teacher Talk: Successful English for Academic Purposes Classroom Practices in a Global Campus
}

\author{
Namsook Kim \\ University at Buffalo, USA
}

\begin{abstract}
Drawn on the sociocultural paradigm, I examined teacher-student communication with emphasis on teacher's talk and its role on international students' learning English as a Second Language in an English for Academic Purposes classroom in a global campus in the U.S. Developmental data analyses of class observations, teacher and student interviews, and documents led to finding multidimensional characteristics of Critical Teacher Talk (CTT). I also found evidence of the role of CTT on production-process-affective aspects of learning English as an International Language. The findings further shed insights on the need to train and practice Critical International Language Pedagogy with the triadic principles-transnational culture building, critical caring, and authentic learning-among international higher education educators and teachereducators.
\end{abstract}

Keywords: English as a Second Language, English as an International Language, English for Academic Purposes, global education, international higher education, multilingualism, teacher-student communication

Spurred by economic and technological globalization (Stromquist, 2007), colleges and universities worldwide participate strategically in growing internationalization as "process of integrating an international, intercultural, or global dimension in the purpose, function, or delivery of postsecondary education” (Knight, 2003, p. 2). Cross-border international student mobility is a major form of transnational higher education worldwide (Organization for Economic Cooperation and Development, 2004). Accordingly, higher 
education in the U.S. as a global model for contemporary international higher education encounters new impact on policies and practices as the worldwide trends of accelerating globalization (Altbach \& Knight, 2007) and ensuing internationalization (Stromquist, 2007) are expected to continue. In particular, considering international student enrollments in colleges and universities in the U.S. that mark continual records high during the 2006-2015 period (Institute of International Education, IIE, 2015), economic, academic, and cultural benefits of transnational student mobility foresee unprecedented growth (NAFSA, n.d.).

However, it begs a question whether institutions' and educators' readiness and success keep pace with the current international student mobility trend. Further, it is worth noting that little mainstream attention is paid to non-degree students including those enrolled in Intensive English programs whereas the majority of the international students study for their academic degrees. Considering the fact that Intensive English for Academic Purposes is ranked the seventh in top fields of study of international students, it is a tall order to include in the strategic efforts to envision higher education practices the need of the neglected population of 49,233 students, $5 \%$ of total international students, a 13.3 percent increase from the previous year (IIE, 2015).

Thus, this study aims to explore the key features of successful English for Academic Purposes (EAP) educational practices in class with international learners of English as a Second Language (ESL). The overarching questions that guided this study follow:

1. What is the nature of teacher-student verbal interaction during EAP classroom instructional time?

2. In what ways, if any, does the teacher's talk influence international students' learning English?

\section{THEORETICAL FRAMEWORK}

Language proficiency is understood from the pedagogical standpoint as 'process' - mediated by a myriad of individual and sociocultural factors-in the continuum of developing "mastery of skills and knowledge" (Ravitch, 2007, p. 173) for a target language, rather than a permanent end-state of a given linguistic ability. Motivated by first and second language acquisition literature on caretaker speech and foreigner talk (Ferguson, 1975), teacher talk, as a conceptual construct, means teacher's speech adjusted as a function of the proficiency of language learners in teaching and learning contexts (Gass \& Selinker, 2008). As such, teacher talk needs to be conceptualized in the perspective of 'development' to respond to the multivoiced complexities of learner language (Wertsch, 1991). Previous research on teacher talk has contributed to addressing the ultimate goals of 
research on classroom instruction that makes a difference in learning (Chaudron, 1988; Norris \& Ortega, 2001).

Still, it is important to note a paradigmatic gap in the research efforts in that previous inquiries were predominantly grounded on a formalist, psycholinguistic epistemology (Eckman, 1994) that views learning solely as an individual cognitive activity measured in 'product' or tests. Considering constant, transnational interactivity in new times, this study turns to learning in 'process' or 'participation' (Robbins, 2003) for further investigation and is drawn on sociocultural perspective that "recognizes the central role that social relationships and culturally constructed artifacts play in organizing uniquely human forms of thinking (Lantolf, 2004, p. 31)". In so doing, "cognition can be systematically investigated without isolation it from social context." (Lantolf \& Thorne, 2006, p. 1) Active participation in dialogically mediated zone of proximal development (Vygotsky, 1978) leads to learner transition from intermental to intramental psychological planes toward language internalization (Vygotsky, 1978) through "the proximal next stage that may be visible through participation in collaborative activity.” (Lantolf \& Thorne, 2006, p. 20) In this sociosemiotic understanding, dialogue (Bakhtin, 1981, 1986) is "the social event of verbal interaction implemented in an utterance or utterances" (Vološinov, 1973, p. 94). Further, the verbal performance of dialogue is an act of intersubjectivity (Rommetveit, 2003) or social identities of interlocutors who engage in a cooperative struggle (Lantolf \& Thorne, 2006) as each speaker attempts to make their own meaning or sense (Vygotsky, 1986) but in simultaneous response to another's sense.

\section{RESEARCH METHOD}

\section{Research Design and Participants}

I chose qualitative case study tradition (Creswell, 1998) to develop an in-depth analysis and enriched understanding of the particularity and complexity of the single case of effective teacher talk bounded in the fourweek EAP classroom (Stake, 1995). The ESL class selected as an exemplar of successful intensive EAP instruction was located at a public university that was one of the most internationalized universities in the U.S. in terms of student enrollments. Anna King (pseudonym), the teacher, was reputed, among her students and other students of the institute, to be "patient", "neutral", and "very good" (student interviews) and successful in her goal to "help them to become better writers in English for Academic Purposes and for work purposes" (teacher interview). Anna, an African-American female in her fifties, with master's degree in reading specialization, had more than 28 years of ESL teaching experience and directed the intensive EAP program. Anna's class cohort that met two hours on all weekdays consisted 
of 16 international students with diverse backgrounds of nationality, first language, gender, age, personality, and English language proficiency. English was spoken as a lingua franca among the transnational students from Japan, Korea, Taiwan, France, and Turkey. Most of the students shared instrumental motivation to learn English to enter a graduate-level program in the U.S. My dual role as a researcher was to learn about the cultural meanings of classroom dialogue (Spradley, 1980) and to interpret the emerging meanings communicable with the larger audience (Stake, 1995).

\section{Procedure}

I chose theory-based, purposeful sampling strategy (Miles \& Huberman, 1994) to locate and select the exemplary case. To improve trustworthiness, I collected data from different points of time (Stake, 1995) and from multiple sources for triangulation (Mathison, 1988): (a) audiotaped, non-participant class observations and field-notes (Creswell, 1998; Spradley, 1980; Wolcott, 1988), (b) audiotaped, introspective semistructured interviews (Seidman, 1998) with the teacher and focal students and one retrospective member-checking interview (Ely, 1991) with the teacher after the end of the semester, (c) documents of daily class instructional materials and student work, and (d) my researcher's log that included annotated field-notes, analytical memos, literature memos, and preliminary category charts.

Upon consent, all observed classes were audio-taped to grasp "the finer details of communicative interaction” (Kasper \& Rose, 2002, p. 66). I also took detailed field-notes, adapted from Creswell's observational protocol (1998, p. 129), to collect not only salient but also less salient but potentially critical elements of non-verbal, contextual data in the classroom discourse (Kasper \& Rose, 2002). Spradley's language identification, verbatim, and concrete principles (1980) guided my note-taking in the field. The protocol interview questions for the teacher addressed such topics as personal backgrounds, the goal of teaching and learning in this class, the topics and styles of the teacher's verbal communication, and the role of teacher's talk in general. Similarly, focal students were asked about their learning experience and goal at the institute, success stories and difficulties in this class, the topics of classroom conversation, strategies to solve difficulties encountered in class, and the role of this teacher's talk in class, and also talk patterns among other teachers.

Also, for theory triangulation, data were constantly analyzed and reviewed with relevant literature. In addition, for methodological triangulation, within my spiral analysis, I used different methods of analysis toward progressive focusing through three developmental stages: Stage One (Preliminary Analysis) with data management and preliminary annotation, Stage Two (Descriptive Analysis) with detailed annotation and analytical 
memoing, and Stage Three (Focused Analysis and Naturalistic Generalizations) with continuous categorical aggregation and naturalistic theme generalization through developing category charts.

\section{FINDINGS}

Figure 1 ("Key features of critical teacher talk") depicts the major characteristics of successful verbal interactional practices in the EAP classroom that helped international students succeed in a global campus. The findings suggest that successful teacher-student communication is meaningfully different from everyday talk that is defined as "the ordinary kinds of communicating people do in schools" (Tracy, 2002, p. 5) in that the international students distinguished Anna King's talk in this class from that in the other EAP classes in which all participating international students enrolled. Four dimensions of the distinctive teacher talk include Comfortable, Dialogic, Mediated, and Purposeful Dimensions.

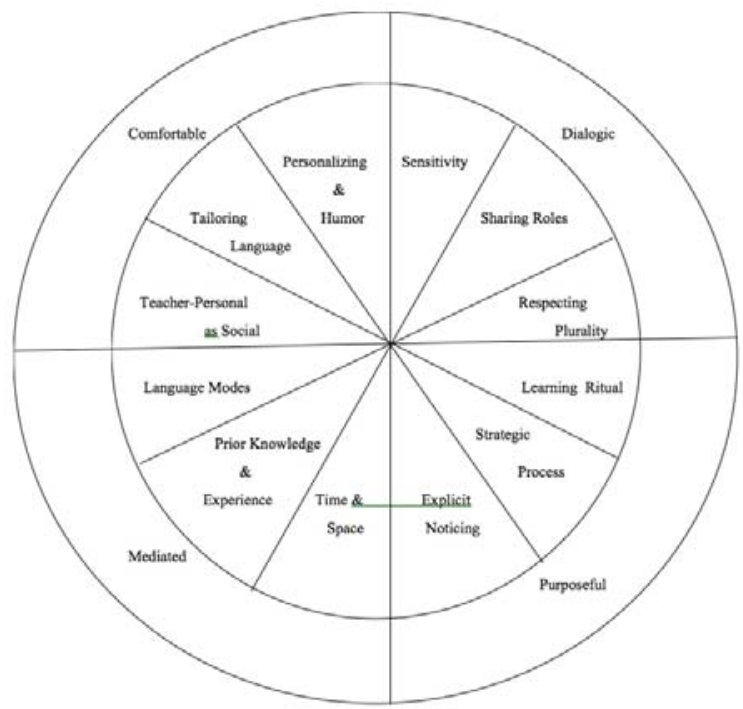

Figure 1. Key features of critical teacher talk

\section{Comfortable Talk toward Critical Caring}

The first area of distinction in Anna's pedagogic talk is the comfort zone that she created in the EAP classroom. Her supportive talk successfully "initiat[ed] a social space for mediation of collaborative composing" (Miller \& McVee, 2012) and helped her international students and herself to coconstruct a safe space for dialogic, mediated, and purposeful learning to 
occur. Anna realized Comfortable Talk by means of such discursive strategies as (a) sharing teacher's personal stories, (b) tailoring teacher's classroom language, and (c) personalizing and using humor. The interdependent discursive strategies contributed altogether to "building a relationship with the students” (teacher interview).

Making teacher-personal social in critical caring relationship. Feeling comfortable with a teaching figure in class may have been a culture shock for the international students who came from cultures where they were more familiar with vertical teacher-student power relations. Their teacher, the most experienced authority in the EAP program, was most willingly and openly sharing her personal stories whenever her examples were instrumental in helping the learners toward her goal: education for growth in reality. Real learning took place when, for example, Anna gave personal cross-cultural examples ("While I was in South America") and talked about local events that were new to her pupils. Also, the open-sharing culture that contributed to changing the teacher-student relationship included frequent conversations about the teacher's feelings and thoughts about her own growth in this class- "Students present challenges and you LEARN from the challenges and that's why I appreciate that. I appreciate that about the class, all of you. You know, it's nice to be able to come into class" (teacher in class).

Building comfort, relationship, and learning was mutual and gradual. According as Anna became more comfortable and built a relationship with her students, more of her "true personality come [came] out" in class (teacher interview). Rapport in the classroom was salient with the increase in her "giving more and more little life hints", "sharing a little truism, a little life", or "mothering". Such critical caring talk reduced power differences and helped "build a RID [relational identity] that is the foundation for further interactions" that, as educational resources, improve learner power, identity, agency, and investment, and learning (Boxer \& Cortés-Conde, 2000, p. 206).

Tailoring classroom language toward motivational framing. Anna's utterance tailoring was multi-fold. She tailored her language by not simplifying it. It was contrary to well-known foreigner talk (Ferguson, 1975) that many native speakers of English would do in their casual or pedagogic conversation with speakers with other language backgrounds. Also, Anna often provided implicit corrective feedback upon students' developmental errors-“I eat medicine.” Instead of explicit negative correction, she referred to the intended answer as "a better one"- "Oh, you could say that [eat]. And I would use take, to take medicine.” Anna was mindful of selecting words to motivate the students. When all her students 
regarded English grammar as "confusing” and "difficult”, Anna chose to use "challenging” rather than "difficult” to motivate student development:

[If the students say it's difficult] they don't think they can learn.it....You rise because of the challenge....They should challenge themselves. Go to the next level....So, think about that I talk about and go to the next level. Take yourselves higher. Did you come to stay at the same level? No! Go to the next level. And most of them do, most of them. I'm happy to see [change], after that speech [laughs]. (teacher interview)

The teacher's mindful tailoring of her speech led to framing (Goffman, 1974) the ways the students saw the multi-discursive learning context. Routinized in class, the teacher's motivational behavior (Dörnyei \& Ushioda, 2013) influenced the diverse learners' behavior to make resilient efforts and achieve the goal of multilingualism.

\section{Personalizing and engaging humor toward authentic languaging.} Personalizing was "the first way to get the students to have the relationship with you and to know that the teacher cares." (teacher interview) To do so, Anna called on them as individuals ("How about the next one, Michael? Anybody else, Miki?") and used students' real names in the examples to practice a new sentence structure ("It's easy for Cynthia to pass the TOEFL or for me to pass the TOEFL, okay?”). Anna's talk used humor with meaning potential (Halliday, 1978) as in their grammar problem solving game: “This is a big one. Ying, Ying doesn't get it? It goes to somebody else. I'm gonna ask you, Yuko. Go ahead for seven dollars. [whole class laughter]" Numerous incidents of humor followed by shared laughter strengthened my first impression of the class: "Class of Smiles" (analytical memo). Through personalized languaging (Swain, 2006), Anna activated shared local knowledge (Widdowson, 1998) of the class and localized language the meaning of which the students could readily infer as it was personal and authentic. Shared humor, as the response and respect to each other, shed insight into symmetry in classroom power and the high level of engagement in class (Mariage, 2001).

\section{Dialogic Talk toward Empowering Inclusion}

Anna's classroom discourse exemplified genuine dialogue as "communication between simultaneous differences (Clark \& Holquist, 1984, p. 9)”. As a "non-authoritarian, authoritative” leader (Morson, 2004), Anna "attempted to comprehend the complex factors that make dialogue possible. (p. 9)"; then she was attentive to students' emergent needs as "a good friend and advisor" (student interview) and sought to make possible "reciprocal" 
dialogue (student interview) by (a) answering with sensitivity, (b) sharing roles, and (c) respecting plurality.

Answering with sensitivity for student development. Genuine dialogue in this class related to notably sensitive answerability (Hestenes, Cassidy, \& Niemeyer, 2004; Holquist, 2002; Wertsch, 1991). In other words, Anna "worked very hard to listen" (teacher interview) to her students and, reciprocally, she was "totally understood" (student interview) by them. Anna's sensitivity even responded to students' unsaid utterances in anticipation of them ("prolepsis", Rommetveit, 1979)—“Michael, what were you gonna say? You have looked at me." Through referential questions, prompts, revoicing (O’Connor \& Michaels, 1993), acknowledgment, follow-up, and confirmation, Anna's seamlessly responsive talk (Cassidy \& Buell, 1996) created "temporary framework for construction progress” (Cazden, 1983) or scaffolding (Wood, Bruner, \& Ross, 1976) and led to peripheral learners' transformation into full participants in the interactive learning environment (Lave \& Wenger, 1991). Anna not only scaffolded student development in the cognitive dimension but also made affective utterances to empower them to challenge and feel successful and "confident" because "confidence [is] the key to the student's being able to do well” (teacher interview).

Sharing roles for empowerment. Anna transferred control and shared ownership of ideas and process with the students to engage and support their participation (Berry, 2006). In this class, knowledge or skills were not deposited in learners' passive minds as in "banking education" (Freire, 2000). Rather, Anna continued to be "opening up the floor to everyone" (teacher interview) in order not to "allow someone to dominate the class". The students became significant "part of that plan" because "this [class] is, after all, your [students'] class." Students as significant contributors received credit for their contribution and decided lesson transitions and points of discussion ("I wanna go back to something /// Younghoon does ask me this now and Hyunsun asks me also"). Numerous incidents of students' and teacher's uptake in this class indicated the level of engagement and signaled active learning (Ferdig \& Roehler, 2003-2004). Further, as coteachers, students checked answers with and taught their peers ("You can go and listen to Ying and Yuko") according to Anna's belief in peer learning and student agency toward learning (Roth, 2002): "[Students] learn something quickly from their partners // The partner explained it in a better way" (teacher interview).

Respecting plurality towards real pedagogy. Unlike desired reality, transnational students often live and study in an assimilatory, either/or 
world. Further, language learners' competency to recognize or produce prescriptively accurate structures is often mistakenly considered to be the sole indicator of learning. By contrast, Anna's talk drew on true plurality of Bakhtinian, both/and epistemology that celebrates cultural-specific relations over universality (Clark \& Holquist, 1984; Holquist, 2002): "We're learning formal grammar in here but when you go to the real world outside the classroom, you're gonna hear this, and this, and this, and this. That's one thing. But also, there are multiple ways to say something and that's the grammar class is all about.” (teacher interview)

\section{Mediated Talk toward Multimodal Expansion}

Anna's talk-in-interaction was mediated by available concepts and cultural entities (Lantolf, 2000; Lantolf \& Thorne, 2006; Vygotsky, 1978). She designed multimodal elements including language modes, prior knowledge and experience, and temporal and spatial elements toward her students' New Learning (Kalantzis \& Cope, 2008).

Oral and written language modes as meaning-mediating resources. Oral language constituted the linguistic and audio elements of multimodal learning (New London Group, 2000). For linguistic design, Anna tried different sentence structures - statements, questions, or non-inverted questions - to make her intention understood, paraphrased using synonyms to facilitate students' understanding, and analyzed the structure of student's utterance using grammar terms. For audio design, Anna read aloud the problem, thought aloud her private speech for modeling, asked students in pairs to read aloud, and "gave meaning to the sentence" (teacher interview) by changing voice tone. To promote visual learning, Anna referred to the textbook essay to "show them [students] a lot of model essays" (teacher interview), pinpointed the sentence or paragraph on the book, and wrote down examples on the board to see because it was "important for the language learners to see what we're talking about" and "[writing] on the board [will] direct their attention // Their seeing it and reading it hopefully will lock it in.” (teacher interview)

Prior knowledge and experience as meaning-mediating resources. Anna used students' prior knowledge and experience to mediate social learning (Vygotsky, 1978), first, by intertextualizing knowledge and experience from familiar to unfamiliar, and then by distributing knowledge and experience from social to individual. Students' familiar knowledge and experience from other EAP classes, their lessons from previous weeks, and back in their countries were available designs to build on for New Learning (New London Group, 2000). Thus Anna's intertextualizing beyond mere juxtaposition of texts (Bloome \& Egan-Robertson, 1993) created "richly 
textured opportunities” (Goldenberg, 1993) for mediated development through spontaneous/familiar concepts toward scientific/grammatical ones (Vygotsky, 1978). Further, Anna's talk expanded distributed knowledge (Gee, 2004) in this class community through shared feedback ("Those are good, Cynthia. Alright, everybody, let me have your attention for a minute, Everyone!"), student answer revoicing, and pair languaging ("With partners, don't do it by yourself”). Such distributed processes promoted opportunities for individual externalizations of their subjective knowledge and experience in the social space toward internalization (Chen \& Hung, 2002).

Time and space as meaning-mediating resources. Anna redesigned time and space as "the forms of the most immediate reality" (Clark \& Holquist, 1984, p. 59). Her explicit spatial redesigning was at work when she kept the open door as a welcome sign and arranged mindful seating ("Alert! Alert! Two Japanese students sitting together....Red light is on. Rang, rang, rang, rang”). Anna designed temporal elements when managing timed agenda, keeping time during small-group work, revisiting a certain topic at different times to "review something every day you did the day before or a week ago" (teacher interview), and maintaining sufficient wait time to elicit students' contribution. In the concrete ways of redesigning, time and space added values of meaning-making potential (Clark \& Holquist, 1984).

\section{Purposeful Talk toward Conscious Cultivation}

Anna's talk-in-interaction was a dynamic action toward the conscious goal of learning (Robbins, 2003). Through her talk, Anna sought to cultivate a new classroom culture with learning rituals, strategic processes, and explicit noticing intervention.

Building a learning ritual. As Anna affirmed during the interview, “There's something done every single lesson." Repeatedly, she reminded the students of the sitting rule, made sure to ask questions before making lesson transitions. This way, Anna's verbal scaffolds were "rhythmic repetition" (Tusting, 2000) so that the pattern was recited as a "cycle" in the community of learners. Due to the synchronized rituals, Anna's lesson was reputed to be the "organized" one in the institute, which resulted in her students' "confidence in the lesson, in the teacher and also in themselves" and, further, "inspires them and encourages them to work harder" as a "cohesive group" (teacher interview). Students felt "comfortable” with their signature rules because "the purpose of the rules is [was] to help people"; therefore "they [the rules] worked well” (student interview).

Cultivating a strategic process. Strategy instruction was the conscious part of learning designing. Anna told the students problem solving strategies, 
gave them such learning tips as writing to learn to write ("You really need to write some of these yourself to really understand it") or using a checklist to review their own writing process, guided them to learning such resources as a useful website, and provided them with mini lessons. One exemplar mini lesson was that of "tolerance hat" that emphasized the need for tolerance of ambiguity:

To learn grammar, you must have tolerance for ambiguity, and we talked about what that meant. Tolerance, high tolerance of ambiguity. You have to be able to // stand something that you can't understand. Get to tolerate that you don't understand it. Don't expect to get it first. First time we go over the book, you might be confused. It's after you work through it and work through the sentences. I explain it more. You work some more and then you get it. It's not always like math (laughs) .... It's not one plus one is two. (laughs) It's more like one plus one is sometimes two, sometimes two and a half (laughs) and sometimes it's not two at all (laughs).... Grammar, learning a language is not always precise. There's a lot of ambiguity.

This type of strategic learning lessons added insights on the interpersonal dimension of scaffolding (Stone, 1993) in that Anna helped the students to "reduce their frustration" that they often felt about developmental errors and to understand each other better thus "build cohesiveness among the classroom” (teacher interview).

Promoting explicit noticing intervention. Instructional intervention at the point of need is a crucial element in effective instruction although every error should not be pointed out for correction unless it interferes communication as advocated in focus-on-form instruction (Doughty \& Williams, 1998). Anna maintained the optimal level of verbal intervention when correcting students' errors in terms of form or meaning and identifying their weakness areas on which they needed to work. Her interventional scaffold was not a discrete-item structural drill but provided guided treatment. Anna guided the students to avoid being obsessed about the structure but to make "a story" for communication ("To make sense, you have to have meaning. You can't put it in any old sentence....So, what's the story?”).

\section{DISCUSSION AND CONCLUSIONS}

This study explored the lived experience of international language students in the U.S. with focus on successful EAP classroom interactional discourse in general and the effective educator's classroom language in particular. The 
implications of the study call for critical dialogue on the current footing of international higher education and future directions.

\section{Toward Accomplishing Equity and Excellence in International Higher Education}

A central purpose of American higher education is known as fostering the preparation of talented young people as the nation's human capital; principles of equity and excellence should guide national and institutional commitment to realizing the goal (Bowen, Kurzweil, \& Tobin, 2005). Toward equity, not only American students with diverse sociocultural backgrounds but also an increasing number of international students who also constitute the current student body of American higher education need to be included in every consideration and implementation of policies and practices. Rational response to equitable international higher education should rid business practice of viewing international students as mere revenue sources that, in fact, may not lead to additional income (Cantwell, 2015). Thus, toward excellence in leading contemporary international higher education, it is a tall order to reexamine and improve the quality of every diverse student's educational environment and experience on the global or internationalizing campus.

\section{Toward Understanding English as an International Language as Multilingual and Multicultural Competencies}

The present times of globalization, internationalization, and transnationalism necessitate all speakers' achieving an advanced proficiency in world languages and multilingualism as part of their global citizenship and competencies for global civic engagement and economic prosperity in a global society (Brutt-Griffler \& Kim, 2016; Committee for Economic Development, 2006). The contemporary context propels multilingual and multicultural education as a local and global imperative to debunk the hegemonic ideology of English-speaking monolingual supremacy situated in a multilingual society (Shohamy, 2006) and also to build the critical communicative competence repertoire among speakers of all languages including transnational student population. In this regard, multilingual international students in intensive English programs-5\% of total higher education international student body (Institute of International Education, 2015) — are growing assets in global knowledge economy. Thus, a new conceptualization of teaching and learning English as an International Language (EIL) should not limit the focus on the gate-keeping language tests but take into account the multilingual learners' dynamic language and identity development that can be understood in the students' in-class production, participation patterns, and affective dimension as shown in Anna’s EIL class. 


\section{Toward Realizing Critical International Language Pedagogy}

Grounded on the findings, this study proposes new directions on international language education that I term as Critical International Language Pedagogy (CILP). CILP repurposes the primary medium of instruction in that an effective educator's classroom language plays a critical role in learners' acquiring world languages as a source of learner input (Gass \& Selinker, 2008), a motivator of transnational languaculture (Agar, 1994; Risager, 2006), and, a semiotic toolkit to mediate language learning and identity development (Vygotsky, 1978). Three intertwined principles of CILP that utilizes teacher's effective classroom verbal communication-that I term as Critical Teacher Talk (CTT) —as the main mediator are: (a) Transnational Culture Building, (b) Critical Caring, and (c) Authentic Learning. CILP intends to reform the core of the educational practice rather than seeking curriculum revisions on the surface (Bruner, 1971), by making deep change in the microculture of the multivoiced classroom community (Wertsch, 1991) where dynamic bilingualism/multilingualism (Garcia, 2011) as assets and rights is a celebrated norm and goal and distributed power relations are collectively created and practiced. CILP is also built on the modeling-dialogue-practice-confirmation components of caring pedagogy (Noddings, 2005) that denotes an effective educator's conscious, relational capacities conducive to redesigning available multilingual, multimodal resources (New London Group, 2000). Importantly, CILP pursues multilingual and multicultural education for authentic purposes to live a transnational life in an interconnected world by embodying and empowering all transnational learners' internally persuasive languages and cultures (Bakhtin, 1986).

\section{REFERENCES}

Agar, M. (1994). Language shock: Understanding the culture of conversation. New York, NY: William Morrow.

Altbach, P., \& Knight, J. (2007). The internationalization of higher education: Motivations and realities. Journal of Studies in International Education, 11(3/4), 290-305.

Bakhtin, M. M. (1981). Dialogic imagination. Austin: University of Texas Press. Bakhtin, M. M. (1986). Speech genres \& other late essays. Austin, TX: UT Press.

Berry, R. A. W. (2006). Teacher talk during whole-class lessons: Engagement strategies to support the verbal participation of students with learning disabilities. Learning Disabilites Research \& Practice, 21, 211-232.

Bloome, D., \& Egan-Robertson, A. (1993). The social construction of intertextuality in classroom reading and writing lessons. Reading Research Quarterly, 28(4), 304-333.

Boxer, D. \& Cortés-Conde, F. (2000). Culture and pragmatics in content-based ESL. In J. K. Hall \& L. S. Verplaetse. Second and foreign language learning through classroom interaction (pp. 203-219). New York: Lawrence Erlbaum. 
Bowen, W. G., Kurzweil, M. A., \& Tobin, E. M. (2005) Equity and excellence in American higher education. Charlottesville, VA: U of V Press.

Bruner, J. (1971). The process of education reconsidered. In Robert Leeper (Ed.), Dare to care/dare to act: Racism and education (pp. 19-32). Washington, DC: Association for Supervision and Curriculum Development.

Brutt-Griffler, J., \& Kim, N. (2016). Multilingualism and e-learning. In C. Haythornthwaite, R. Andrews, J. Fransman \& E. Meyers (Eds.), The Sage handbook of e-learning research (2nd ed., pp. 187-208). Thousand Oaks, CA: Sage.

Cantwell, B. (2015). Are international students cash cows? Examining the relationship between new international undergraduate enrollments and institutional revenue at public colleges and universities in the US. Journal of International Students, 5(4), 512.

Cassidy, D. J., \& Buell, M. (1996). Accentuating the positive?: An analysis of teacher verbalizations with young children. Child and Youth Care Forum, 25, 403-414.

Cazden, C. (1983). Adult assistance to language development: Scaffolds, models, and direct instruction. In R. P. Parker \& F. A. Davis (Eds.), Developing literacy: Young children's use of language (pp. 3-17). Newark, DE: International Reading Association.

Chaudron, C. (1988). Second language classrooms: Research on teaching and learning. New York: Cambridge University Press.

Chen, D., \& Hung, D. (2002). Personalised knowledge representations: The missing half of online discussions. British Journal of Educational Technology, 33, 279-290.

Clark, K., \& Holquist, M. (1984). Mikhail Bakhtin. Cambridge, MA: Harvard University Press.

Committee for Economic Development. (2006). Education for global leadership: The importance of international studies and foreign language education for US economic and national security. Retrieved from https://www.ced.org/pdf/Education-for-Global-Leadership.pdf.

Creswell, J. W. (1998). Qualitative inquiry and research design: Choosing among five traditions. Thousand Oaks, CA: Sage.

Dörnyei, Z., \& Ushioda, E. (2013). Teaching and researching motivation ( $2^{\text {nd }}$ ed.). New York, NY: Routledge.

Doughty, C., \& Williams, J. (1998). Pedagogical choices in focus on form. In C. Doughty \& J. Williams (Eds.), Focus on form in classroom second language acquisition (pp. 197-261). New York, NY: CUP.

Eckman, F. R. (1994). The competence-performance issue in second-language acquisition theory: A debate. In E. E. Tarone, S. M. Gass \& A. D. Cohen (Eds.), Research methodology in second-language acquisition (pp. 3-15). New Jersey: Lawrence Erlbaum.

Ely, M. (1991). Doing qualitative research: Circles within circles. New York, NY: Routledge Falmer, Taylor \& Francis.

Ferdig, R. E., \& Roehler, L. R. (2003-2004). Student uptake in electronic discussions: Examining online discourse in literacy preservice classrooms. Journal of Research on Technology in Education, 36, 119-136. 
Ferguson, C. A. (1975). Towards a characterization of English foreigner talk. Anthropological Linguistics, 17, 1-14.

Freire, P. (2000). Pedagogy of the oppressed. New York: Continuum.

García, O. (2011). From language garden to sustainable languaging: Bilingual education in a global world. NABE Perspectives, November-December 2011, 5-9.

Gass, S. M., \& Selinker, L. (Eds.). (2008). Second language acquisition: An introductory course (3rd ed.). New York, NY: Routledge.

Gee, J. P. (2004). Situated language and learning: A critique of traditional schooling. New York, NY: Routledge.

Goffman, E. (1974). Frame analysis: An essay on the organization of experience. Lebanon, NH: Northwestern University Press.

Goldenberg, C. (1993). Instructional conversations: Promoting comprehension through discussion. The Reading Teacher, 46, 316-326.

Halliday, M. A. K. (1978). Language as social semiotic: The social interpretation of language and meaning. Baltimore, MA: University Park Press.

Hestenes, L. L., Cassidy, D. J., \& Niemeyer, J. (2004). A microanalysis of teachers' verbalizations in inclusive classrooms. Early Education and Development, 15(1), 23-38.

Holquist, M. (2002). Dialogism: Bakhtin and his world ( $2^{\text {nd }}$ ed.). New York, NY: Routledge.

Institute of International Education. (2015). Open doors 2015: Fast facts. Retrieved from http://www.iie.org/Research-and-Publications/OpenDoors/Data/Fast-Facts\#.V1h_eZErK00

Kalantzis, M., \& Cope, B. (2008). New Learning: Elements of a science of education. New York: Cambridge University Press.

Kasper, G., \& Rose, K. R. (2002). Pragmatic development in a second language. Malden, MA: Blackwell.

Knight, J. (2003). Updated internationalization definition. International Higher Education, 33, 2-3.

Lantolf, J. P. (Ed.). (2000). Sociocultural theory and second language learning. Oxford: Oxford University Press.

Lantolf, J. P. (2004). Sociocultural theory and second and foreign language learning: An overview of sociocultural theory. In K. van Esch, \& O. St. John (Eds.), New insights into foreign language learning and teaching (pp. 13-34). Frankfurt am Main: Peter Lang.

Lantolf, J. P., \& Thorne, S. L. (2006). Sociocultural theory and the genesis of second language development. New York: Oxford University Press.

Lave, J., \& Wenger, E. (1991). Situated learning: Legitimate peripheral participation. Cambridge: Cambridge University Press.

Mariage, T. V. (2001). Features of an interactive writing discourse: Conversational involvement, conventional knowledge, and internalization in "Morning Message". Journal of Learning Disabilities, 34, 172-196.

Mathison, S. (1988). Why triangulate? Educational Researcher, 17, 13-17.

Miles, M. B., \& Huberman, A. M. (1994). Qualitative data analysis: An expanded sourcebook (2nd ed.). Thousand Oaks, CA: Sage.

Miller, S. M., \& McVee, M. B. (2012). Changing the game: Teaching for embodied learning through multimodal composing. In S. M. Miller \& M. B. McVee 
(Eds.), Multimodal composing in classrooms: Learning and teaching for the digital world (pp. 130-152). New York: Routledge. doi:10.4324/9780203804032

Morson, C. S. (2004). The process of ideological becoming. In A. F. Ball \& S. W. Freedman (Eds.), Bakhtinian perspectives on language, literacy, and learning (pp. 317-331). New York: Cambridge University Press.

NAFSA Association of International Educators. (n.d.) Explore international education.

Retrieved

from

http://www.nafsa.org/Explore_International_Education/Impact/Data_And_ Statistics/NAFSA_International_Student_Economic_Value_Tool/

New London Group. (2000). A pedagogy of Multiliteracies designing social futures. In B. Cope \& M. Kalantzis (Eds.), Multiliteracies: Literacy learning and the design of social future (pp. 9-37). New York: Routledge.

Noddings, N. (2005). The challenge to care in schools: An alternative approach to education (2nd ed.). New York: Teachers College Press.

Norris, J. M., \& Ortega, L. (2001). Does type of instruction make a difference? Substantive findings from a meta-analysis review. Language Learning, 51, 157-213.

O'Connor, M. C., \& Michaels, S. (1993). Aligning academic task and participation status through revoicing: Analysis of a classroom discourse strategy. Anthropology and Education Quarterly, 24, 318-335.

Organization for Economic Cooperation and Development. (2004). Internationalisation and trade in higher education: Opportunities and challenges. Retrieved from http://www.oecd.org/edu/skills-beyondschool/33730019.pdf

Ravitch, D. (2007). EdSpeak: A glossary of education terms, phrases, buzzwords, and jargon. Alexandria, VA: Association for Supervision and Curriculum Development.

Risager, K. (2006). Language and culture: Global flows and local complexity. Clevedon, UK: Multilingual Matters.

Robbins, D. (2003). Vygotsky's and A. A. Leontiev's semiotics and psycholinguistics: Applicants for education, second language acquisition, and theories of language. Westport, CT: Praeger.

Rommetveit, R. (1979). Deep structure of sentence versus message structure: Some critical remarks on current paradigms, and suggestions for an alternative approach. In R. Rommetveit \& R. Blakar (eds.), Studies of language, thought and verbal communication. London: Academic Press.

Rommetveit, R. (2003). On the role of "a psychology of the second person" in studies of meaning, language, and mind. Mind, Culture, and Activity: An International Journal, 10(3), 205-218.

Roth, W.-M. (2002). Being and becoming in classroom. New York: Ablex.

Seidman, I. (1998). Interviewing as qualitative research: A guide for researchers in education and the social sciences (2nd ed.). New York, NY: TC Press.

Shohamy, E. (2006). Imagined multilingual schools: How come we don't deliver” In O. García, T. Skutnabb-Kangas and M. Torres-Guzman (Eds.), Imagining multilingual schools, languages in education and globalization (pp. 171-183). Clevedon: Multilingual Matters. 
Spradley, J. P. (1980). Participant observation. New York: Holt, Rinehart, and Winston.

Stake, R. E. (1995). The art of case study research. Thousand Oaks, CA: Sage.

Stone, C. A. (1993). What's missing in the metaphore of scaffolding? . In E. Forman, N. Minick \& C. A. Stone (Eds.), Contexts for learning: Sociocultural dynamics in children's development (pp. 169-183). New York: Oxford University Press.

Stromquist, N. P. (2007). Internationalization as a response to globalization: Radical shifts in university environments. Higher Education, 53,81-105.

Swain, M. (2006). Languaging, agency and collaboration in advanced second language proficiency. In H. Byrnes. (Ed.), Advanced language learning: The contribution of Halliday and Vygotsky (pp. 95-108). New York, NY: Continuum.

Tracy, K. (2002). Everyday talk: Building and reflecting identities. New York: The Guilford Press.

Tusting, K. (2000). The new literacy studies and time: An exploration. In D. Barton, M. Hamilton \& R. Ivanic (Eds.), Situated literacies: Reading and writing in context (pp. 35-53). New York, NY: Routledge.

Vološinov, V. N. (1973). Marxism and the philosophy of language. New York, NY: Seminar Press.

Vygotsky, L. S. (1978). Mind in society. Cambridge, MA: Harvard University Press. Vygotsky, L. S. (1986). Thought and language. Cambridge, MA: The MIT Press.

Wertsch, J. V. (1991). Voices of the mind: A sociocultural approach to mediated action. Cambridge, MA: Harvard University Press.

Widdowson, H. G. (1998). Context, community, and authentic language. TESOL Quarterly, 32, 705-716.

Wolcott, H. (1988). Ethnographic research in education. In R. Jaegger (Ed.), Complementary methods for research in art education (pp. 187-206). Washington, DC: American Education Research Association.

Wood, D., Bruner, J. S., \& Ross, G. (1976). The role of tutoring in problem solving. Journal of Child Psychology and Psychiatry, 17, 89-100.

NAMSOOK KIM, Ph.D. is Clinical Assistant Professor in the Department of Educational Leadership and Policy at the State University of New York at Buffalo Graduate School of Education where she also serves as Assistant Director in the Center for Comparative and Global Studies in Education. Dr. Kim has more than 20 years of professional experience in training educators and education leaders in the transformative intersections of language and culture in the context of globalization, multilingualism, and multiculturalism, and assisting international business, in the U.S. and Korea. Email:nkim3@buffalo.edu 